\title{
18. Mapping the terrestrial gamma radiation dose
}

\author{
DAVID BEAMISH ${ }^{\mathrm{I}}$
}

How to cite this chapter:

Beamish, D., 2016 'Mapping the terrestrial gamma radiation dose' in M.E. Young (ed.), Unearthed: impacts of the Tellus surveys of the north of Ireland. Dublin. Royal Irish Academy.

DOI:10.3318/ 978-1-908996-88-6.ch18
The Tellus airborne radiometric data have enabled assessments of environmental radioactivity levels in unprecedented detail across the north of the island of Ireland. Both the natural (geological) and man-made (industrial) contributions to public exposure from ionising terrestrial gamma radiation are considered. Over much of the area the gamma-ray flux is significantly attenuated by peat and organic soil but relatively highly radioactive rocks are exposed in places, notably in the south-east of the surveyed area. The results indicate that across the area the effective dose from terrestrial gamma radiation is everywhere within the acceptable level, subject to the inherent spatial averaging of the measurements. The airborne survey also revealed areas where industry has concentrated or exposed naturally occurring radioactive material, including quarries and fly-ash piles.

\section{INTRODUCTION}

Since the days of Marie Curie it has been appreciated that exposure to ionising radiation may be hazardous to health. The first definition of a unit of radiation was made in 1928. Units of absorbed dose, the actual energy absorbed in the tissue being irradiated, are now used and are given as $1 \mathrm{~J} \mathrm{~kg}^{-1}$ or 1 gray (Gy). The gray can be used for any type of radiation but it does not express the biological effects from different types of radiation. The absorbed dose rate in air $\left(\mathrm{nGy} \mathrm{h}^{-1}\right)$ is used to indicate the gamma ray intensity in the air from radioactive materials in the earth and atmosphere. Equivalent dose rate relates the absorbed dose in human and biota tissue and organs to the effective biological damage. The current SI unit of equivalent dose is the Sievert (Sv). The Tellus airborne radiometric data sets provide estimates of the absorbed dose rate in air $\left(\mathrm{nGy} \mathrm{h}^{-1}\right)$; these may then be converted to equivalent annual dose rate estimates.

Terrestrial gamma radiation (the natural flux from rocks and soils) accounts for approximately $16 \%$ of the total annual dose of natural ionising radiation to which the population is exposed (Watson et al., 2005). This terrestrial component arises due to primordial radionuclides that were synthesised during the creation of the planet, and has always accompanied life on Earth. Both humans and biota are exposed to an annual dose rate. The average annual dose to the UK population is estimated to be $2.7 \mathrm{mSv}$, with $2.2 \mathrm{mSv}$ of this

${ }^{\mathrm{I}}$ British Geological Survey, Keyworth. 
coming from natural radiation (Hughes et al., 2005). According to Watson et al. (2005), the annual UK exposure from terrestrial gamma radiation is about one third that from the inhalation of radon gas (see Appleton and Hodgson, Chapter 20, this volume; Hodgson and Young, Chapter 2, this volume). The data considered here do not assess the potential exposure from terrestrial radon.

Since the natural flux is largely determined by soil and associated parent geological material, personal annual exposure to terrestrial gamma radiation is determined by the home location, the localities visited and the amount of time spent indoors and outdoors, within a geological framework. The annual exposure of the UK population from all natural and artificial sources is further evaluated in Watson et al. (2005).

Terrestrial gamma dose rates largely reflect the natural variation of potassium, uranium and thorium across the environment. The high spatial resolution airborne surveys, and their continuous local to regional scale, allow assessments of both the geological background and its spatial variability together with localised concentrations due to industrial/ technological processes. The data sets provide a basis for studies of dose rates derived from both NORMs (naturally occurring radioactive materials) and TENORMs (technologically enhanced naturally occurring radioactive materials). Watson et al. (2005) discuss both subjects in relation to UK assessments.

\section{MATERIALS AND METHODS}

Estimates of radioelement concentrations are available from the Tellus airborne surveys and the ground geochemistry. The geochemical soil-sample estimates are referred to here as 'in-soil' and the airborne estimates as 'in-air'. The latter provide a measure of the airabsorbed dose rate directly above the ground surface. Radium $\left({ }^{226} \mathrm{Ra}\right)$ is the fifth daughter decay product of uranium $\left({ }^{238} \mathrm{U}\right)$ and is the parent of the natural gas radon $\left({ }^{222} \mathrm{Rn}\right)$, responsible for radon exposure of the population (i.e. at locations where radon gas may build up). An airborne radiometric survey includes measurements that are used to minimise the potential radon contributions in the air-column. When effective, the airborne data then provide estimates of the ground concentration of the radium-radon parent uranium. Airborne measurements of uranium levels can then be used as one of the supporting techniques in the estimation of indoor radon levels alongside indoor radon measurements and digital geological maps (Appleton et al., 2008; Appleton and Hodgson, Chapter 20, this volume).

The present study considers air absorbed dose (AAD) defined, using the airborne ground concentration estimates (IAEA, 2010), as:

$$
\operatorname{AAD}\left(\mathrm{nGy} \mathrm{h}^{-1}\right)=13.078 \times \% \mathrm{~K}+5.675 \times \mathrm{eU}+2.494 \times \mathrm{eTh}
$$

where radionuclide equivalent concentrations, $\mathrm{eU}$ and $\mathrm{eTh}$, are in $\mathrm{ppm} . \% \mathrm{~K}$ is percentage potassium. The combined dose measurement covers the energy range from 1.37 to 
2.81 MeV and excludes contributions from artificial (man-made) sources. The airborne absorbed dose rate values may be converted into units of $\mathrm{Bq} \mathrm{kg}^{-1}$ if comparison with international and UK legislation is required. A range of radionuclide conversion factors have been reported in the literature over the years and these are summarised by Beamish (2014).

Effective dose is a sum of multiples of equivalent doses in separate human organs each with a specific weighting factor. As noted in UNSCEAR (2000), to estimate annual effective doses, account must be taken of (a) the conversion coefficient from absorbed dose in air to effective dose and (b) the indoor-outdoor occupancy factor. The average numerical values of those parameters vary with the age of the population and the climate at the location considered. The UNSCEAR committee used $0.7 \mathrm{~Sv} \mathrm{~Gy}^{-1}$ for the conversion coefficient from absorbed dose in air to effective dose received by adult organs and 0.8 for the indoor occupancy factor, i.e. the fraction of time spent indoors and outdoors is 0.8 and 0.2 , respectively. The annual effective dose rate (AEDR) in $\mathrm{mSv} \mathrm{y}^{-1}$ may be calculated from the $\mathrm{AAD}$ rate using the above factors to give:

$$
\operatorname{AEDR}\left(\mathrm{mSv} \mathrm{y}^{-1}\right)=\operatorname{AAD}\left(\mathrm{nGy} \mathrm{h}^{-1}\right) * 8760(\mathrm{~h}) * 1.0 * 0.7\left(\mathrm{~Sv} \mathrm{~Gy}^{-1}\right) * 10^{-6}
$$

The factor of 8760 represents the number of hours (h) in a year and an occupancy of unity (meaning totally indoors) has been applied. The conversion indicates that the airborne dose rate values of 10,100 and $1000\left(\mathrm{nGy} \mathrm{h}^{-1}\right)$ produce equivalent annual effective dose estimates of $0.061,0.61$ and $6.1 \mathrm{mSv}$, respectively. The statutory UK limit on the amount of radiation to which the general public may be exposed, in excess of natural background and excluding medical exposure, is $1 \mathrm{mSv}$ per annum (Watson et al., 2005).

\section{RESUlTS}

Previous studies of dose rates across the UK noted the remarkable skew (to low values) of the original Tellus radiometric data set (Beamish, 2013). The composite Tellus radiometric data used here have had water bodies (areas $>5 \mathrm{~km}^{2}$ ) removed. The unusually extensive areas of reduced radioactivity result from the attenuation of the signal by peat bogs, which cover some $17 \%$ of Northern Ireland (Beamish, 2013). However, when considering dose rates it is usually the high value end of the distribution that has most relevance to both NORM and TENORM investigations.

\section{NORM contributions}

Figure 18.1 summarises the low and high values of the observed distribution of dose rates obtained from the two Tellus surveys. The low values $\left(<8 \mathrm{nGy} \mathrm{h}^{-1}\right)$ are shown in black-grey and the high values $\left(>60 \mathrm{nGy} \mathrm{h}^{-1}\right)$ are shown in yellow-red. The widely distributed low values display a high spatial correspondence with areas of peat. At the scale shown, it is evident that high values are associated with a subset of the granite outcrops shown in pink. 

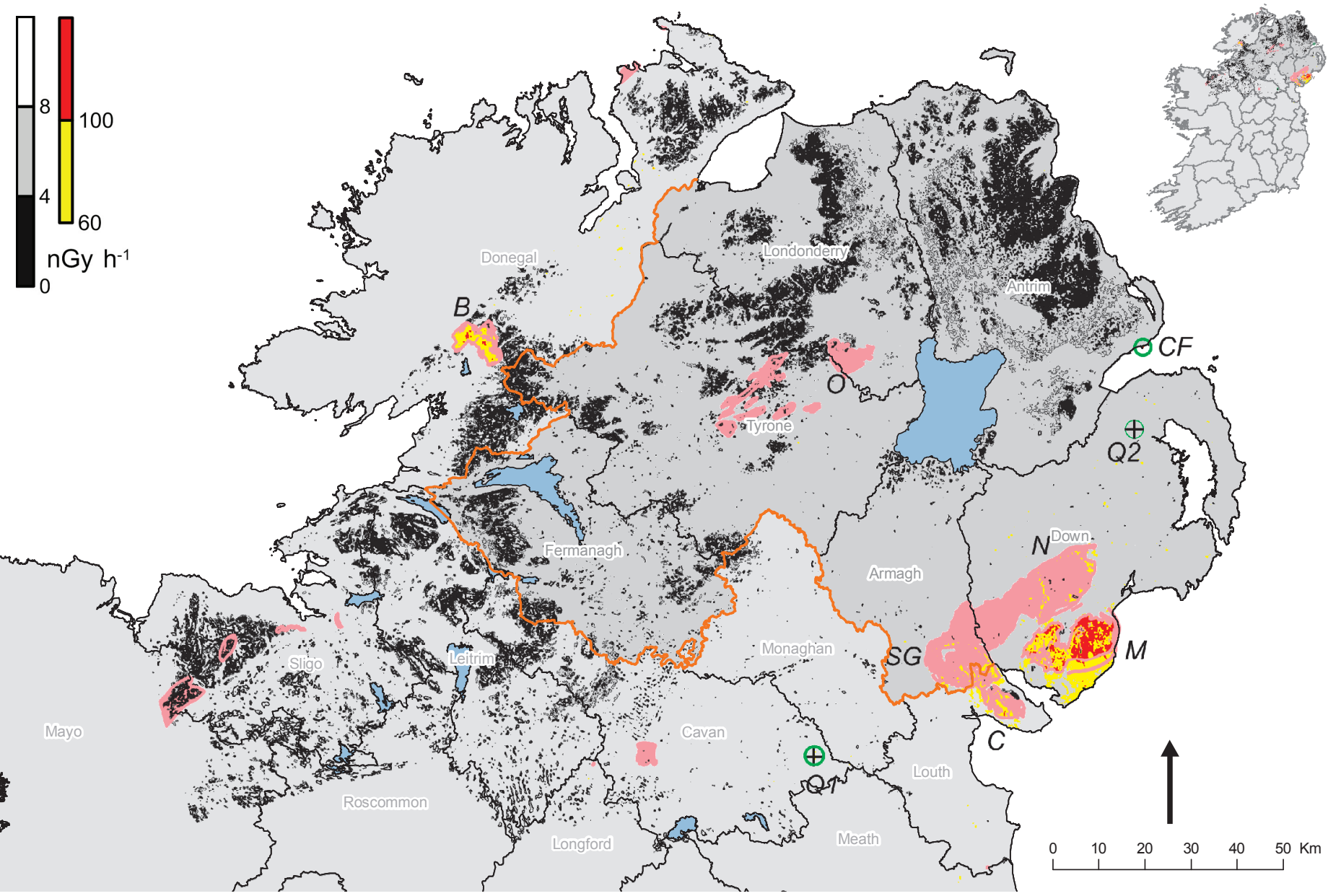

The most spatially persistent set of high values are found in the eastern Mourne Mountains granite complex with other, less extensive zones being found within the Slieve Gullion, Carlingford and Newry granites. The Caledonian Barnesmore granite (B) in southern Donegal also displays a persistent zone of high values, largely confined to the western margins. The Ordovician granites $(\mathrm{O})$ within the Midland Valley terrane are not associated with high values despite the absence of peat.

The maximum dose values within the data set occur in the eastern Mourne Mountains and range from 267 to $320 \mathrm{nGy} \mathrm{h}^{-1}$; the precise value depends on factors applied with merging of the Tellus survey data sets. In order to assess the spatial behaviour of the dose rate values, it is useful to additionally consider soil and water information. Figure 18.2 shows an area centred on the outcrop of Mourne granite complex (the inner polygon in grey) with coloured contours of high dose rate $\left(>150 \mathrm{nGy} \mathrm{h}^{-1}\right)$. Areas of peat are shown using transparent brown and water bodies are in blue. The high values are largely confined to the outcrop although it can be noted (Fig. 18.1) that values $>60 \mathrm{nGy} \mathrm{h}{ }^{-1}$ extend to the south of the outcrop. The locations of the zones of high values are spatially complex and it is probable that the areas of extensive peat modify (attenuate) the flux pattern observed. It is worth noting that the granitic responses noted in Fig. 18.2 also have a concomitant elevated response in uranium values.

Figure 18.1. Air absorbed dose rate estimates obtained by the Tellus surveys. Low value amplitudes $\left(<8 \mathrm{nGy} \mathrm{h}^{-1}\right)$ in grey scale, high amplitudes in yellow-red ( $>60 \mathrm{nGy}$ $\left.\mathrm{h}^{-1}\right)$. Pink areas are granite outcrops $(\mathrm{B}=$ Barnsmore, $\mathrm{C}=$ Carlingford, $\mathrm{M}=$ Mournes, $\mathrm{N}$ = Newry, $\mathrm{O}=$ Ordovician, $\mathrm{SG}$ = Slieve Gullion). Q1 and Q2 are locations of two quarries discussed in the text. $\mathrm{CF}=$ Carrickfergus. 


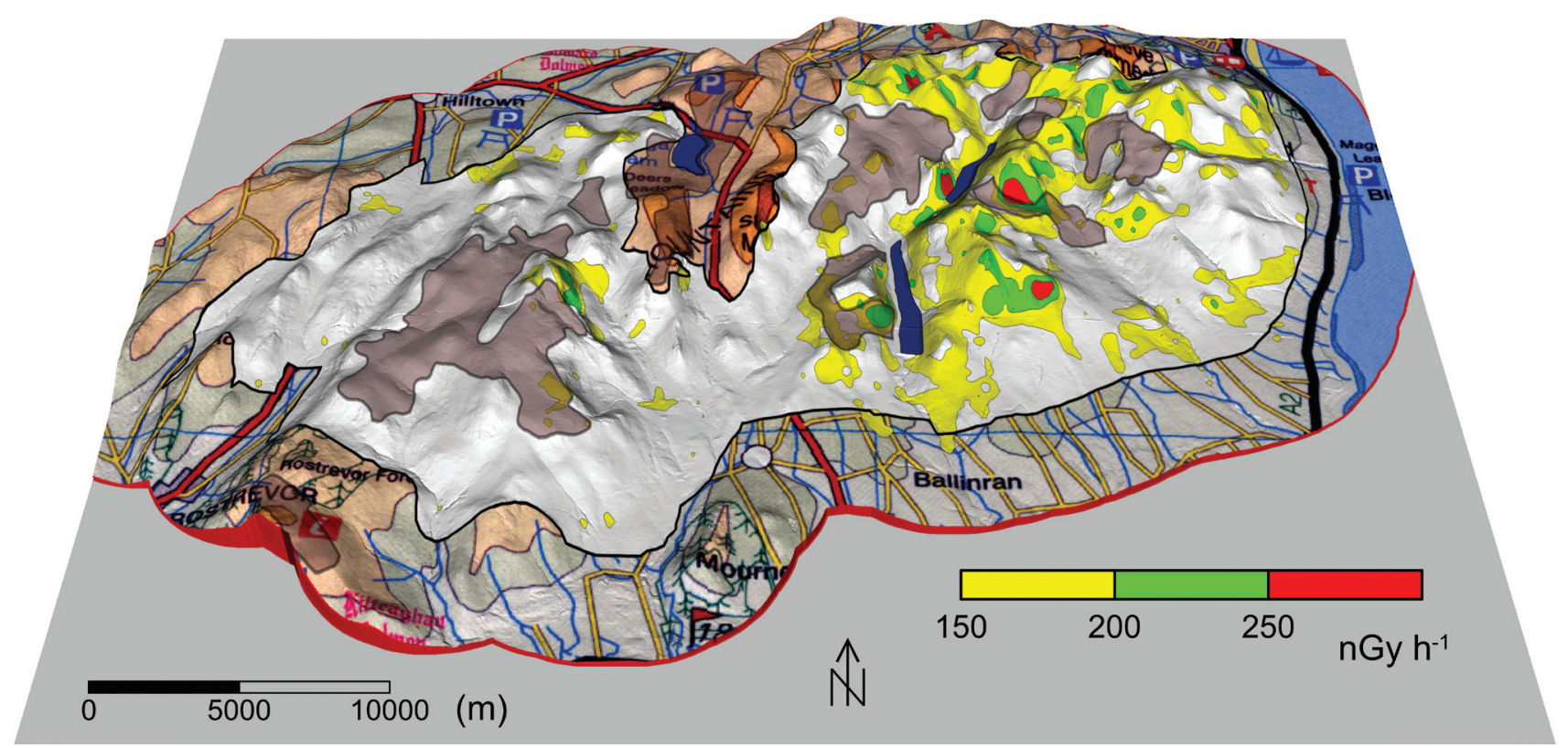

Figure 18.2. 3D perspective view (see north arrow) showing area of Mourne Mountains granite outcrop (in grey), with a $2 \mathrm{~km}$ extension showing base map, and draped on a base digital terrain model (DTM). Colour contours of high values of dose rate in yellow-greenred. Peat areas in brown, water bodies in blue.
The bedrock geology across the survey area is complex and any assessment of the radiometric response is complicated by the soil modification to the flux. The environmental component of annual dose rate is undoubtedly related to the main place of residence of each individual. It is possible to exploit the uniform coverage of the airborne survey data to provide estimates of city and town dose rates. When the complexities of the geological and soil responses are fixed (as would be expected at the housing-district scale), a more direct, population-related assessment can be undertaken. Given a spatial database of defined local authority areas, it is possible to conduct the analysis by size of population or by area; here we use the former. The analysis was conducted using areas with a population $>5000$ individuals (2001 census).

Statistical analysis of the dose rates within 37 population centres of Northern Ireland is summarised in the box-whisker plot of Fig. 18.3, which is arranged in decreasing population size (from 276,705 to 5076). The majority of towns have dose rates below $50 \mathrm{nGy}$ $\mathrm{h}^{-1}$. Thirteen locations with higher dose rate levels are identified in red. These areas are predominantly underlain by granitic bedrock but there are additional contributions from the variable ground cover, so the method is effective in distinguishing the actual 'at-home' terrestrial gamma exposure levels experienced by the population. A similar analysis conducted using the Tellus Border data, where granitic areas are less extensive, revealed that the central values were all $<50 \mathrm{nGy} \mathrm{h}{ }^{-1}$. The high value tails of the distributions are also significant, since these reveal more localised high exposure values. The behaviour of the Carrickfergus distribution is very distinctive and is discussed further below. 


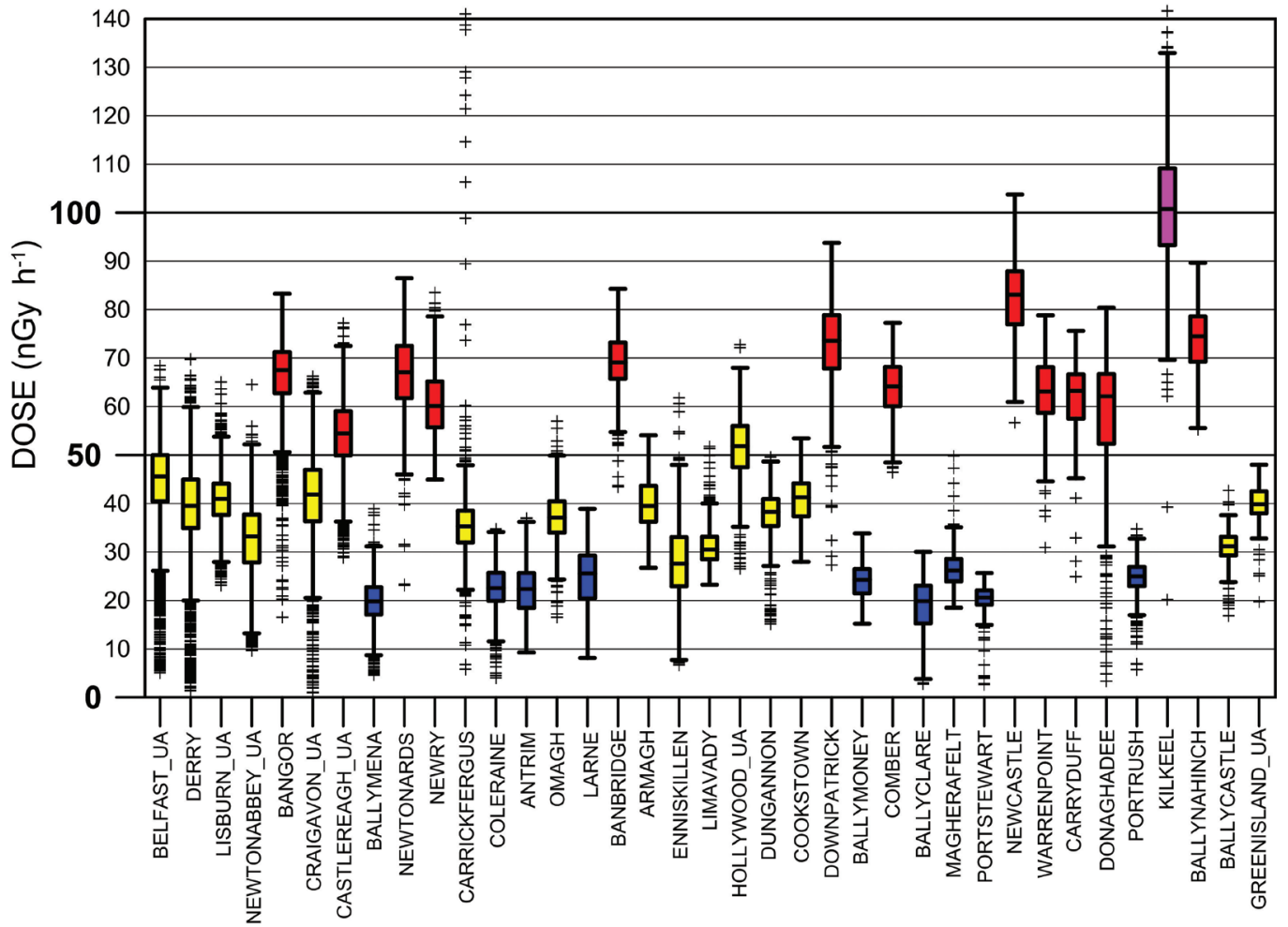

TENORM contributions

The main central values for the Carrickfergus distribution (Fig. 18.3) lie in the range 30-40 $\mathrm{nGy} \mathrm{h}^{-1}$, but high values (data outliers) exceed this by a factor of 3. Kilroot Power Station, based in Carrickfergus, is Northern Ireland's largest power station. The waste material from combustion (fly ash) is contained within a landfill area on the coast. Figure 18.4 shows the detailed airborne observation points (dots) looking inland from the coast and centred on the landfill. High dose values are colour contoured and it is evident that the high values are confined to the landfill and that the data offer discrimination in the levels observed across the site. Further analysis, not shown here, indicates that the high levels are due to elevated concentrations in both thorium and uranium. In the context of other UK airborne data sets, colliery spoil heaps, iron ore mines and processing works and power stations are also marked by relatively high values of all three natural radioelements, but most notably thorium (Lahti and Jones, 2003). Radiometric measurements at ground level display a greater range of radionuclide concentrations due to the spatial averaging (typically $>100 \times 100 \mathrm{~m}$ ) inherent to the airborne measurement.

By their nature, TENORM contributions to high dose rates derive from existing and historical industrial activities and are spatially compact. A range of legacy effects due to many centuries of activity in the UK are reported by Beamish (2014). The largest recorded dose rate observed in modern UK airborne surveys is $579 \mathrm{nGy} \mathrm{h}^{-1}$, from a highly localised
Figure 18.3. Box and whisker plot summarising the statistical behaviour of the airborne dose rate values classified according to the 37 towns of Northern Ireland with a population > 5000. Arranged in order of decreasing population. 


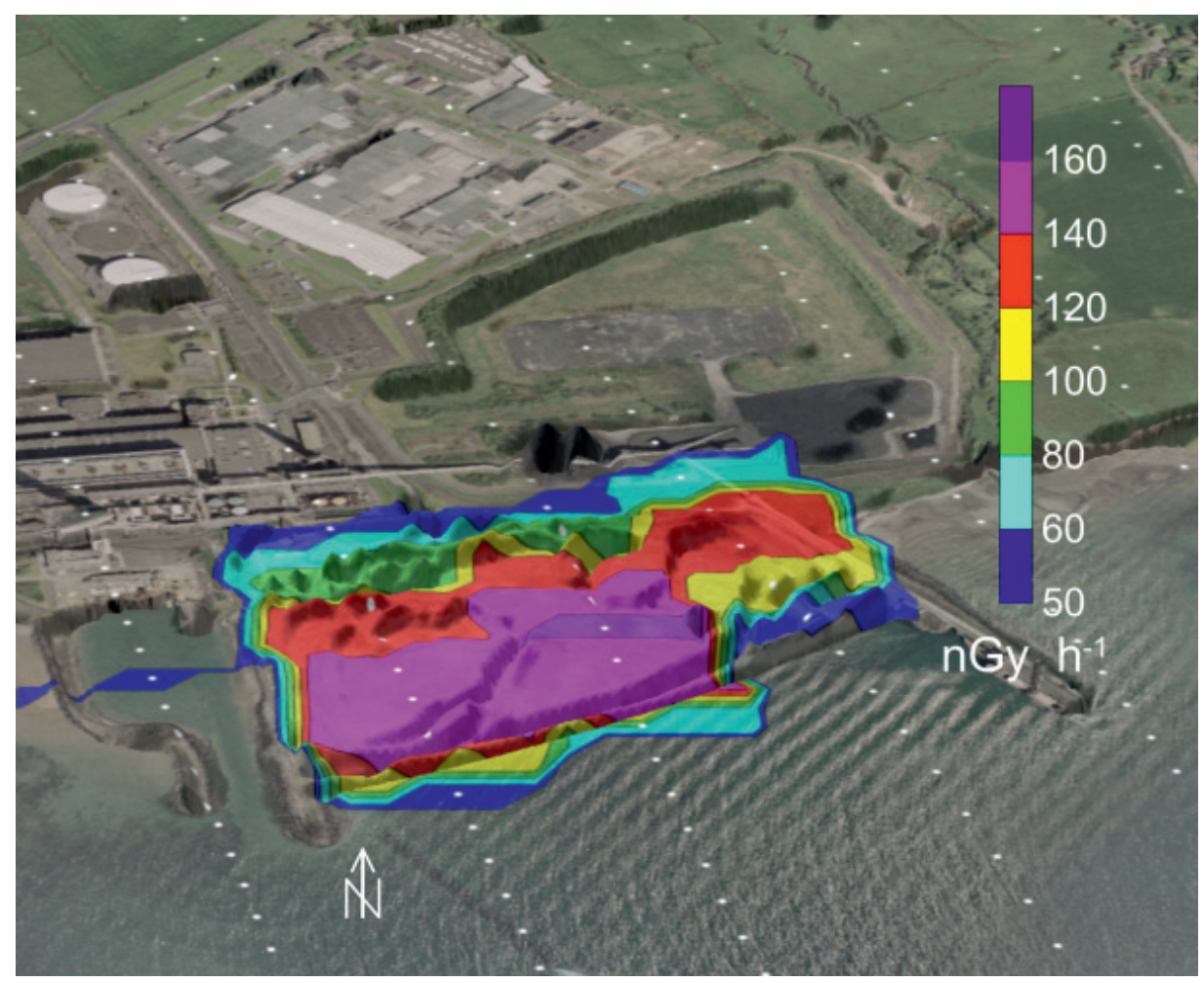

Figure 18.4. 3D perspective view (see north arrow), looking down on coastal landfill adjacent to the Kilroot power station at Carrickfergus. Air photograph draped on DTM.

Colour contours show high values of dose rate. White dots are airborne survey sampling points, along flight lines every

$200 \mathrm{~m}$. zone (predominantly along one flight line) associated with a former uranium mine in the vicinity of the St Austell granite in Cornwall. In the case of the Tellus surveys, TENORM contributions are observed to be typically less than $100 \mathrm{nGy} \mathrm{h}^{-1}$. The relatively high value dose rates shown in Fig. 18.1 use a threshold of $60 \mathrm{nGy} \mathrm{h}^{-1}$. The relatively high values account for only $1 \%$ of the total data. Areas of high dose were examined in relation to base topographical maps and airborne images. A significant proportion of the values occur in the vicinity of existing quarrying and other extractive industries. Two examples of localized detection (identified in Fig. 18.1) are shown in Fig. 18.5; both show the zone of values with dose rate $>60 \mathrm{nGy} \mathrm{h}^{-1}$. Figure 18.5a shows a quarrying operation about $4 \mathrm{~km} \mathrm{SE}$ of Stormont. The main zone is localised on one flight line. Figure $18.5 \mathrm{~b}$ shows a larger quarrying operation in County Cavan, about midway between Bailieborough and Kingscourt, where two separate zones are detected across four flight lines. Site-specific conditions and potential causes of localised high values at a range of existing and former industrial sites across the UK are further discussed by Beamish (2014).

These determinations of TENORM are of course limited to the effects of direct radiation. They do not reflect the potentially greater health hazards of radiation from inhaled radioactive particulates (dust), which if lodged within the body may continue to emit tissue-damaging alpha and beta particles for many years. 

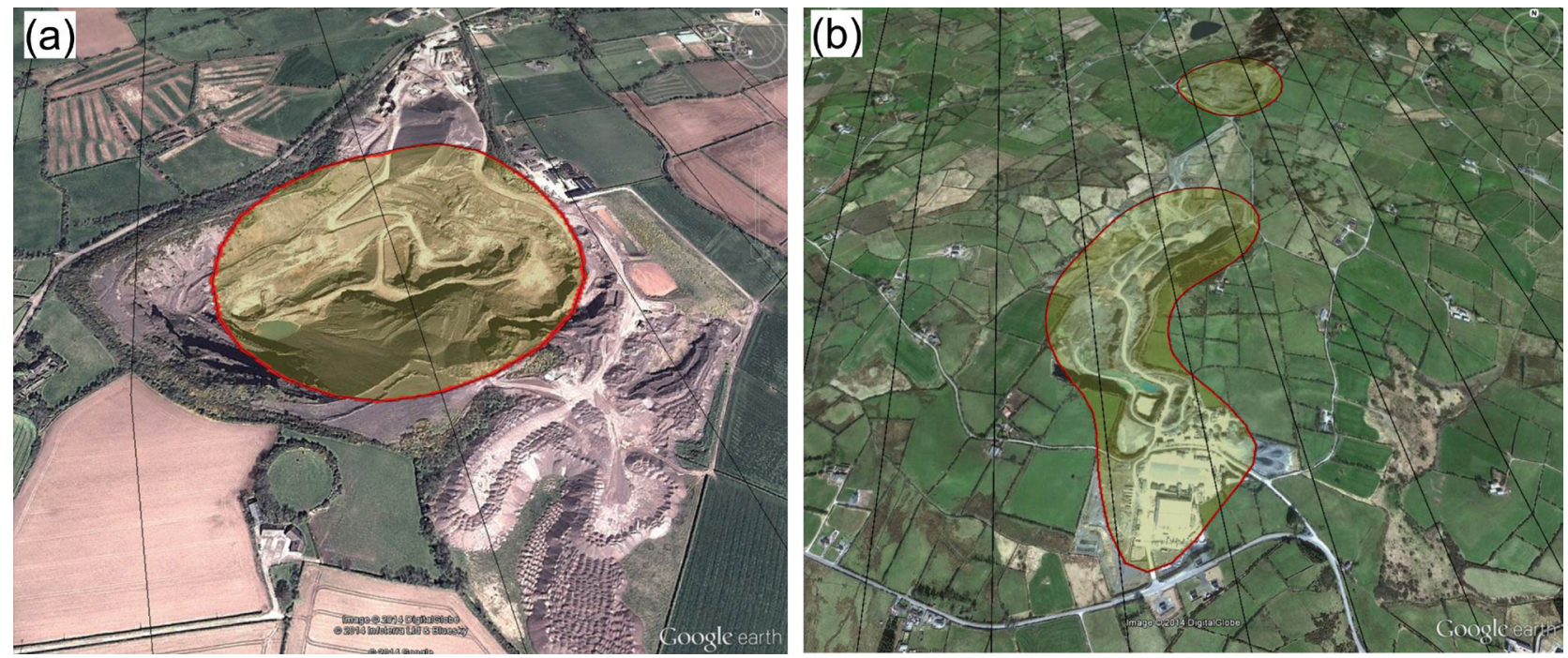

The Chernobyl nuclear accident took place in April 1986 and deposited significant amounts of the man-made radioelement caesium $\left({ }^{137} \mathrm{Cs}\right)$ over an extensive area of Europe. Although in the UK and Ireland this fallout was not directly hazardous to health, in some contaminated areas restrictions were placed on the movement and sale of sheep, which might accumulate caesium by grazing over an extended period.

Radiometric data from the first Tellus survey, alongside other airborne sets, were used to map the caesium $\left({ }^{137} \mathrm{Cs}\right.$ ) distribution (Scheib and Beamish, 2010; Rawlins et al., 2011). The distribution obtained using the combined Tellus data sets is shown in Fig. 18.6, which identified zones and bands where high concentrations were deposited. The areas and bands of high concentration were found to cut across both and high and low topographical features, all soil types and differing land-use areas. The 'banding' in the results obtained was interpreted as representing a series of rain fronts intercepting the Chernobyl plume. Such a full understanding was, in fact, only achieved some 20 years after the accident.

\section{SumMary}

Radiological assessments by bodies such as Public Health England (formerly the Health Protection Agency) and its predecessors have periodically refined assessments of the exposure of the population. The average annual dose from natural radiation remains at 2.23 $\mathrm{mSv}$, with about half of this coming from indoor radon exposure. The average AAD UK dose rate, weighted by the distribution of population, has been found to be $32 \mathrm{nGy} \mathrm{h}^{-1}$. It should be noted that, due to the spatial averaging inherent to the airborne measurements, ground distributions will typically display a higher spatial variance than the values reported here.

The pervasive blanket bog and organic soils, and their water content, attenuate the radioactive flux and therefore screen much of the survey area (say $>25 \%$ ) from potential

Figure 18.5. Two quarry areas with high $\left(>60 \mathrm{nGy} \mathrm{h}^{-1}\right)$ dose rates identified with red contours and transparent infill. The black lines are flight lines (spaced at $200 \mathrm{~m}$ ). Locations are shown in Fig 18.1. The background images are (C) Google Earth. 

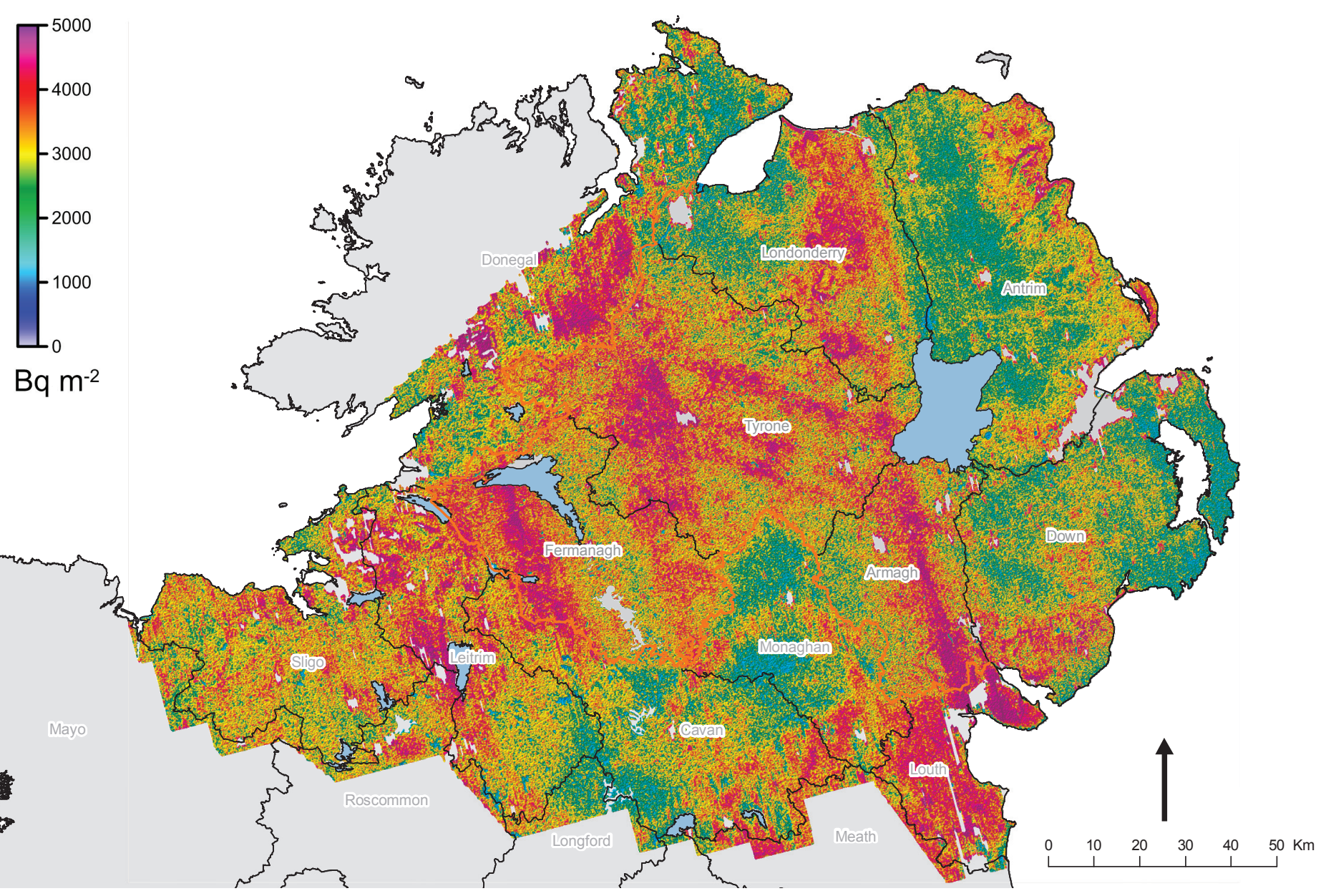

Figure 18.6. The caesium distribution obtained from the Tellus surveys $\left(\mathrm{Bq} \mathrm{m}^{-2}\right)$. The distribution is cut to the coast and water bodies $\left(>5 \mathrm{~km}^{2}\right)$, and high-fly areas $(>180 \mathrm{~m})$ are excluded. high, in-air dose levels. The highest natural background dose rates are found in association with granites. Only a few small areas possess values in excess of $200 \mathrm{nGy} \mathrm{h}^{-1}$ (an effective annual dose rate of $1.23 \mathrm{mSv}$ ). The city-town analysis of dose rates, which covers the major percentage of the population, indicates that central values are routinely below $100 \mathrm{nGy} \mathrm{h}^{-1}$, but one granite location (Kilkeel) has a median value close to $100 \mathrm{nGy} \mathrm{h}{ }^{-1}$.

TENORM contributions are localised and there are many contributions that can be identified, typically at levels below $100 \mathrm{nGy} \mathrm{h}^{-1}$. The fly-ash landfill at Carrickfergus has a localised area providing in excess of $140 \mathrm{nGy} \mathrm{h} \mathrm{h}^{-1}$.

The audit on environmental radioactivity reported here indicates that effective (biological) dose thresholds are within acceptable levels, subject to the inherent spatial averaging of the measurements.

\section{ACKNOWLEDGEMENTS}

This chapter is published with the permission of the Executive Director of the British Geological Survey (NERC).

\section{REFERENCES}

Appleton, J.D., Miles, J.C.H., Green, B.M.R. and Larmour, R., 2008 'Pilot study of the application of Tellus airborne radiometric and soil geochemical data for radon mapping', Journal 


\section{Beamish}

of Environmental Radioactivity, 99, 1687-97. Available at http://nora.nerc.ac.uk/5443/. http://dx.doi.org/10.1016/j.jenvrad.2008.03.011.

Beamish, D., 2013 'Gamma ray attenuation in the soils of Northern Ireland, with special reference to peat', Journal of Environmental Radioactivity, 115, 13-27. Available at http://nora.nerc.ac.uk/500308/. http://dx.doi.org/10.1016/j.jenvrad.2012.05.031.

Beamish, D., 2014 'Environmental radioactivity in the UK: the airborne geophysical view of dose rate estimates', Journal of Environmental Radioactivity, 38, 249-63. Available at http://nora.nerc.ac.uk/508763/. http://dx.doi.org/10.1016/j.jenvrad.2014.08.025.

Hughes, J.S., Watson, S.J., Jones, A.L. and Oatway, W.B., 2005 'Review of the radiation exposure of the UK population', Journal of Radiological Protection, 25, 493-6.

International Atomic Energy Agency (IAEA), 2010 Radioelement Mapping, Nuclear Energy Series, No. NF-T-1.3. Vienna.

Lahti, M. and Jones, D.G. 2003 'Environmental applications of airborne radiometric surveys', First Break, 21, 35-41.

Rawlins, B.G., Scheib, C., Beamish, D., Webster, R., Tyler, A.N. and Young, M.E., 2011 'Landscape-scale controls on the spatial distribution of caesium 137: a study based on an airborne geophysical survey across Northern Ireland', Earth Surface Processes and Landforms, 36, 2, 158-69. Available at http://nora.nerc.ac.uk/13300/. http://dx.doi.org/10.1002/esp.2026.

Scheib, C. and Beamish, D., 2010 'High spatial resolution observations of ${ }^{137} \mathrm{Cs}$ in northern Britain and Ireland from airborne geophysical data', Journal of Environmental Radioactivity, 101, 670-80. Available at http://nora.nerc.ac.uk/12929/. http://dx.doi.org/10.1016/j.jenvrad.2010.03.010.

UNSCEAR (United Nations Scientific Committee on the Effects of Atomic Radiation), 2000 United Nations Scientific Committee on the Effects of Atomic Radiation Report to the General Assembly, with Annexes. Sources and Effects of Ionizing Radiation, Vol. I: Sources. New York. United Nations. Available at http://www.unscear.org/unscear/en/publications/2000_1.html.

Watson, S.J., Jones, A.L., Oatway, W.B. and Hughes, J.S., 2005 Ionising Radiation Exposure of the UK Population: 2005 Review. Chilton, UK. Health Protection Agency report HPA-RPD-001. Available at https://www.gov.uk/government/publications. 
Unearthed: impacts of the Tellus surveys of the north of Ireland

First published in 2016 by the

Royal Irish Academy

19 Dawson Street

Dublin 2

www.ria.ie

Copyright (C) 2016 Royal Irish Academy

ISBN: 978-1-908996-88-6

The articles in this book are open access and distributed under the terms of the Creative Commons Attribution 4.0 licence, which permits unrestricted use, distribution and reproduction in any medium, provided the original authors and source are credited. To view a copy of this licence, visit https://creativecommons.org/licenses/by/4.0/

Except where noted:

Geological mapping for Northern Ireland / Tellus data are provided by the Geological Survey of Northern Ireland.

Geological mapping for Ireland / Tellus Border data are provided by the Geological Survey of Ireland.

Topographic mapping for Northern Ireland is derived from Land and Propery Services Open Data and contains public sector information licensed under the Open Government Licence v3.0. (http://www.nationalarchives.gov.uk/doc/open-governmentlicence/version/3/).

Topographic mapping for Ireland is derived from Ordnance Survey of Ireland Open Data (https://creativecommons.org/licenses/by/4.0/legalcode).

While every effort has been made to contact and obtain permission from holders of copyright, if any involuntary infringement of copyright has occurred, sincere apologies are offered, and the owner of such copyright is requested to contact the publisher.

British Library Cataloguing-in-Publication Data. A catalogue record is available from the British Library.

Design: Alex Donald, Geological Survey of Northern Ireland.

Index: Brendan O'Brien.

Printed in Poland by L\&C Printing Group. 


\section{Table of Contents:}

\section{Prelim}

DOI: https://doi.org/10.7486/DRI.b851k323d

\section{Chapter 1}

The Tellus geosciences surveys of the north of Ireland: context, delivery and impacts

DOI: https://doi.org/10.7486/DRI.st74s528d

\section{Chapter 2}

The Tellus airborne geophysical surveys and results DOI: https://doi.org/10.7486/DRI.t148tx96z

\section{Chapter 3}

The Tellus geochemical surveys, results and applications

DOI: https://doi.org/10.7486/DRI.t722wq645

\section{Chapter 4}

Stakeholder engagement for regional geoscientific surveying: the Tellus Border communications campaign

DOI: https://doi.org/10.7486/DRI.w089fr763

\section{Chapter 5}

Mineral resources and Tellus: the essential balance DOI: https://doi.org/10.7486/DRI.wd37kb12s

\section{Chapter 6}

Gold exploration in the north of Ireland: new targets from the Tellus Projects

DOI: https://doi.org/10.7486/DRI.wh24m696v

\section{Chapter 7}

Using soil geochemistry to investigate gold and base metal distribution and dispersal in the glaciated north of Ireland

DOI: https://doi.org/10.7486/DRI.wm11n3806

\section{Chapter 8}

Critical metals for hightechnology applications: mineral exploration potential in the north of Ireland DOI: https://doi.org/10.7486/DRI.wp98p0649

\section{Chapter 9}

A natural laboratory for critical metals investigations in the Mourne Mountains granites

DOI: https://doi.org/10.7486/DRI.cc08ww45f

\section{Chapter 10}

Geothermal potential of granitic rocks of the Mourne Mountains

DOI: https://doi.org/10.7486/DRI.ff36jm09f

\section{Chapter 11}

Shape and intrusion history of the Late Caledonian

Newry Igneous Complex, Northern Ireland

DOI: https://doi.org/10.7486/DRI.2v248822m

\section{Chapter 12}

Using Tellus data to enhance targeting of volcanogenic massive sulphide mineralisation in the Tyrone Igneous Complex

DOI: https://doi.org/10.7486/DRI.5x226w262

\section{Chapter 13}

The geological significance of electrical conductivity anomalies of the Ordovician- Silurian Moffat Shale Group, Northern Ireland

DOI: https://doi.org/10.7486/DRI.6m31f4149

\section{Chapter 14}

Faults, intrusions and flood basalts: the Cenozoic structure of the north of Ireland

DOI: https://doi.org/10.7486/DRI.90205h306

\section{Chapter 15}

Information for agriculture from regional geochemical surveys: the example of soil $\mathrm{pH}$ in the Tellus and Tellus Border data

DOI: https://doi.org/10.7486/DRI.dv14c8060

\section{Chapter 16}

An ecohydrological investigation of wetlands in the border counties of Ireland: a framework for a holistic understanding of wetland systems DOI: https://doi.org/10.7486/DRI.hd775d90j 
Chapter 17

Assessing nutrient enrichment risk to groundwaterdependent ecosystems in the border counties of Ireland DOI: https://doi.org/10.7486/DRI.k356pk18j

\section{Chapter 18}

Mapping the terrestrial gamma radiation dose

DOI: https://doi.org/10.7486/DRI.k930rb86z

\section{Chapter 19}

Soils and their radiometric characteristics

DOI: https://doi.org/10.7486/DRI.mp495t62g

\section{Chapter 20}

Modelling in-house radon potential using Tellus data and geology to supplement inhouse radon measurements

DOI: https://doi.org/10.7486/DRI.ns06hm86z

\section{Chapter 21}

Determining geochemical threshold values from the Tellus data sets: the examples of zinc and iodine| DOI: https://doi.org/10.7486/DRI.r2087418g

\section{Chapter 22}

Identification of the geochemical signatures of diffuse pollution in the Tellus Border soil data set, using source apportionment

DOI: https://doi.org/10.7486/DRI.wh24m698d

\section{Chapter 23}

Stream sediment background concentrations in mineralised catchments in Northern Ireland: assessment of 'pressures' on water bodies in fulfilment of Water Framework Directive objectives DOI: https://doi.org/10.7486/DRI.x633tf86g

\section{Chapter 24}

Mapping metallic contamination of soils in the Lower Foyle catchment

DOI: https://doi.org/10.7486/DRI.9k42bv355

\section{Chapter 25}

Refining the human health risk assessment process in Northern Ireland through the use of oral bioaccessibility data

DOI: https://doi.org/10.7486/DRI.9p29cr199

\section{Chapter 26}

Combining environmental and medical data sets to explore potential associations between environmental factors and health: policy implications for human health risk assessments

DOI: https://doi.org/10.7486/DRI.9s16dn03n

\section{Chapter 27}

Mapping a waste disposal site using Tellus airborne geophysical data

DOI: https://doi.org/10.7486/DRI.9w03fh87q

\section{Chapter 28}

The use of aero-magnetics to enhance a numerical groundwater model of the Lagan Valley aquifer, Northern Ireland

DOI: https://doi.org/10.7486/DRI.9z90gd711

\section{Chapter 29}

Carbon sequestration in the soils of Northern Ireland: potential based on mineralogical controls DOI: https://doi.org/10.7486/DRI.b277h9556

\section{Chapter 30}

Spatial distribution of soil geochemistry in geoforensics DOI: https://doi.org/10.7486/DRI.b564j6392

\section{End matter}

DOI: https://doi.org/10.7486/DRI.bc38m007j 